\title{
A LARGE BOMBUS NEST FROM MEXICO ${ }^{1}$
}

\author{
By C. D. Michener and W. E. LABerge \\ University of Kansas, Lawrence, Kansas
}

Although many aspects of the bionomics of temperate climate bumblebees are rather well known, little has been published on the biology of tropical species. It therefore seems worthwhile to make known the observations resulting from the excavation of a nest of Bombus medius Cresson. The nest was found at the edge of second growth jungle beside a field 15 miles south of Pujal, San Luis Potosi, Mexico, on June 21, 1953. This is in a region shown as tropical evergreen forest in Leopold's (1950) vegetation map of Mexico. It is near the town of Tamazunchale, on which the following climatic data is available: Rainfall average 63.4 inches per year, most of it falling during the months of June to October. Monthly temperature averages range from $63^{\circ} \mathrm{F}$. for January to $81^{\circ} \mathrm{F}$. for July and August. Minimum temperatures probably reach freezing only once in many years. The bee is a tropical species, ranging from tropical Mexico to Paraguay.

The nest was about four inches below the surface of the ground in a hollow which may have been an old rodent nest. The entrance was a hole about 1.5 inches in diameter. The hollow in which the nest was located was partially filled with decaying strips of bark, leaves, twigs, and the like, on which termites were feeding. The nest itself consisted of an irregular mass of cocoons and cells 10.5 inches in maximum diameter, nearly as large in other diameters, and three to four inches thick. Some of the cocoons were old, their walls whitened with fungus. Some of these old cocoons (about 10\%) were filled with honey and sealed. As elsewhere in the nest, no cocoons used for honey storage were elongated with wax before sealing. For the most part these very old cocoons were at one side of the nest and on its lower surface. The bulk of the nest was made up of

${ }^{1}$ Contribution No. 871 from the Department of Entomology, University of Kansas, Lawrence, Kansas. 
somewhat younger looking cocoons, most of which were full or partially full of honey, although many had only a little honey in the bottom. Most of the cocoons were arranged in clusters of 7 to 11 , each cluster representing a group of young that developed in a single cell. No cocoons large enough to have produced queens were present.

Most pollen pots were made entirely of wax, which like other wax in the nest was soft and black. These pollen pots were up to $18 \mathrm{~mm}$. in diameter and $32 \mathrm{~mm}$. high. Some were empty, others full or partly so. Pollen was also stored in a very few cocoons, and in one or two pollen pots consisting of cocoons lengthened and enlarged with wax.

Cells containing eggs were small, but ranged up to 31 $\mathrm{mm}$. in diameter when the larvae were mature. Several cells contained larvae spinning cocoons and one single larva had pupated.

Remarkably few cocoons contained eggs and larvae, suggesting that reproduction was at a low ebb. This was likely due to the fact that we dug this nest just after the end of the dry season which had been long and intense.

The following is a tabulation of the nest contents:

$\begin{array}{lr}\text { queen } & 1 \\ \text { males } & 0 \\ \text { workers } & 800 \\ \text { pupae } & 1 \\ \text { mature larvae } & 70 \\ \text { medium sized larvae } & 14 \\ \text { small larvae } & 18 \\ \text { larvae of unrecorded size } & \text { approx. } 24 \\ \text { eggs } & 28 \\ \text { empty cocoons } & 804 \\ \text { cocoons with honey } & 1227 \\ \text { large pollen pots with pollen } & 7 \\ \text { small pollen pots with pollen } & 16 \\ \text { empty pollen pots } & 29\end{array}$

From the above tabulation it is evident that the queen must have produced 2183 offspring, of which 2031 had reached maturity before the nest was dug, and of which at least 800 survived until that time. This appears to be 
a record for size in bumblebee colonies, especially when it is realized that most large colonies previously recorded contained numerous males.

Nearly all the adult bees were collected. Most of them were in the nest but a great many were afield. We are much indebted to Mr. I. Slesnick for help in capturing the returning bees, about half of which carried pollen. Bees returned at a rather steady rate from the time excavation

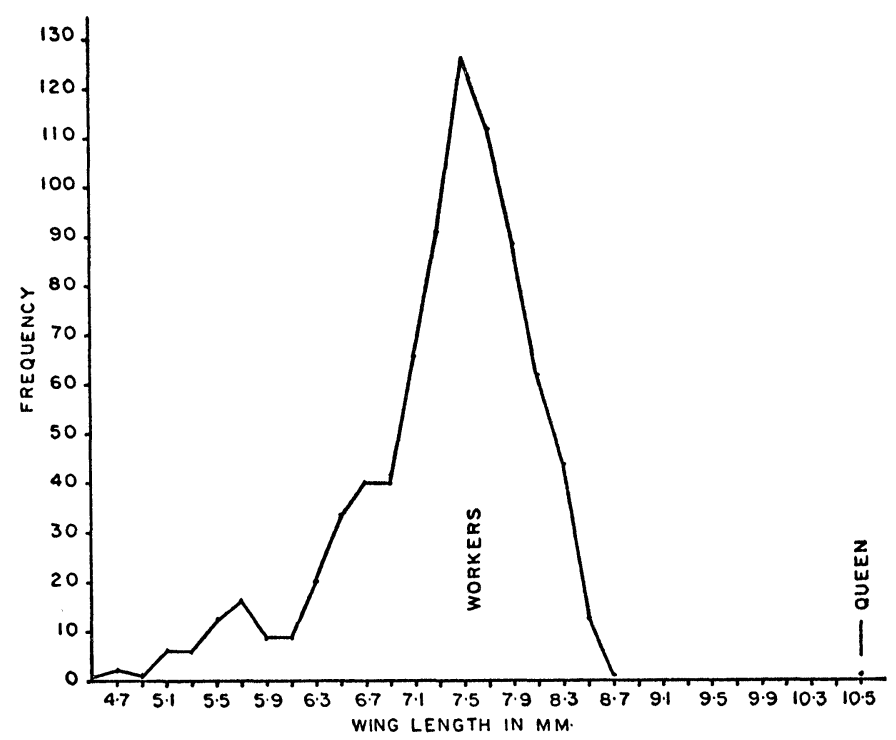

Figure 1. Frequency distribution of the size of the workers and the queen from the nest of Bombus medius Cresson based on wing length. The wings were measured from the proximal end of cell 1st $M$ to the distal end of the marginal cell. We wish to thank Mr. Carl W. Rettenmeyer for taking these measurements.

began at 10:00 a.m. until about noon, and at a progressively reduced rate until 1:00 p.m. when the excavation work was complete. No doubt a few returned after this time and were not captured. These data indicate some foraging trips of very long duration.

As shown in figure 1, measurements of the workers show 
considerable variation, with a wide discontinuity between the largest worker and the queen. All of the very small workers were found in the nest. Casual observations of foraging bees in this area and elsewhere at lower and middle altitudes in Mexico where this species is common indicate that the smallest workers do not visit the flowers, suggesting that a division of labor among workers has progressed farther than that described by Brian (1952) for $B$. agrorum (Fabricius). She found that while most workers of agrorum eventually forage, small ones begin later in life and that a few of the small ones never do so.

Collections of foraging bees made elsewhere in Mexico during July contained a number of queens of $B$. medius. They were visiting flowers just as do queens of temperate climate bumblebees in the spring. This observation, together with the presence of only a single queen in the large nest excavated, throws doubt on von Ihering's (1903) theory that in a Brazilian bumblebee which is either the same as medius or a closely allied species colony multiplication is by swarms. Perhaps the several fecundated queens reported by von Ihering to occur in single nests were mostly young queens which had mated in or temporarily returned to their parental nests.

The colony excavated by us would appear to consist of the progeny of a single queen. It was just renewing activity after a season of reproductive inactivity, probably correlated with the dry season. In spite of its large size, this colony probably had not yet passed through the phase when new queens and males are produced, for no queen cocoons were found in the nest. The disparity in size between the queen and workers and the large number of queens ordinarily produced in Bombus nests make it unlikely that queen cocoons were present, but unrecognized.

In Brazil, von Ihering (1903) observed fecundated queens and some males overwintering in the parental nest. Collections of $B$. medius queens visiting flowers in July suggest that the fecundated queens may pass the season of adversity (dry season combined with the cool season) in the same manner in Mexico. 
Brian, Anne D.

Literature Cited

1942. Division of labor and foraging in Bombus agrorum (Fabricius). Jour. Anim. Ecology, $21: 223-240$.

IHERING，R. vON

1903. Biologische Beobachtungen an brasilianischen Bombus-Nestern. Allgemeine Zeitsch. Ent., 8:447-453.

LEOPOLD, A. StARKER

1950. Vegetation zones of Mexico. Ecology, 31:507-518.

NeW Synonymy of aN AUSTRAlian IRIDOMyrmeX (HyMENOPTERA: FORMICIDAE).-Iridomyrmex biconvexus Santschi, 1928, Bull. Soc. Vaud Sci. Nat., 56: 471, worker (Type loc.: Ringwood, Victoria. Syntypes in Naturh. Mus., Basel; Mus. Comp. Zool.) proves to be the senior synonym of Iridomyrmex foetans Clark, 1929, Vict. Naturalist, Melbourne, $46: 122$, pl. 1, figs. 4, 4a, worker (Type loc.: Cann River, Victoria. Syntypes in Nat. Mus. Vict., Melbourne; Mus. Comp. Zool.) as here noticed for the first time. I have compared syntypes directly, and they are obviously conspecific. The promesonotal suture is mobile, affecting the alitruncal profile. I have found this species abundant in the Dandenongs and Warburton Ranges, Victoria, in medium to wet sclerophyll forest, particularly in those parts dominated by Eucalyptus regnans, although its also occurs down to sea level near Melbourne. Clark also found it common on the Otway Peninsula. In wet E. regnans-treefern gullies of the Warburton Range, this is the dominant ant species up to at least 3,000 feet. In the snow gum-grass areas above this, it is replaced by a similar Iridomyrmex identical with types of I. emeryi Crawley, but perhaps synonymous with some older species name. All ant names mentioned here are perhaps junior synonyms of older names obscurely attached. - W. L. Brown, JR., Museum of Comparative Zoology, Harvard University. 

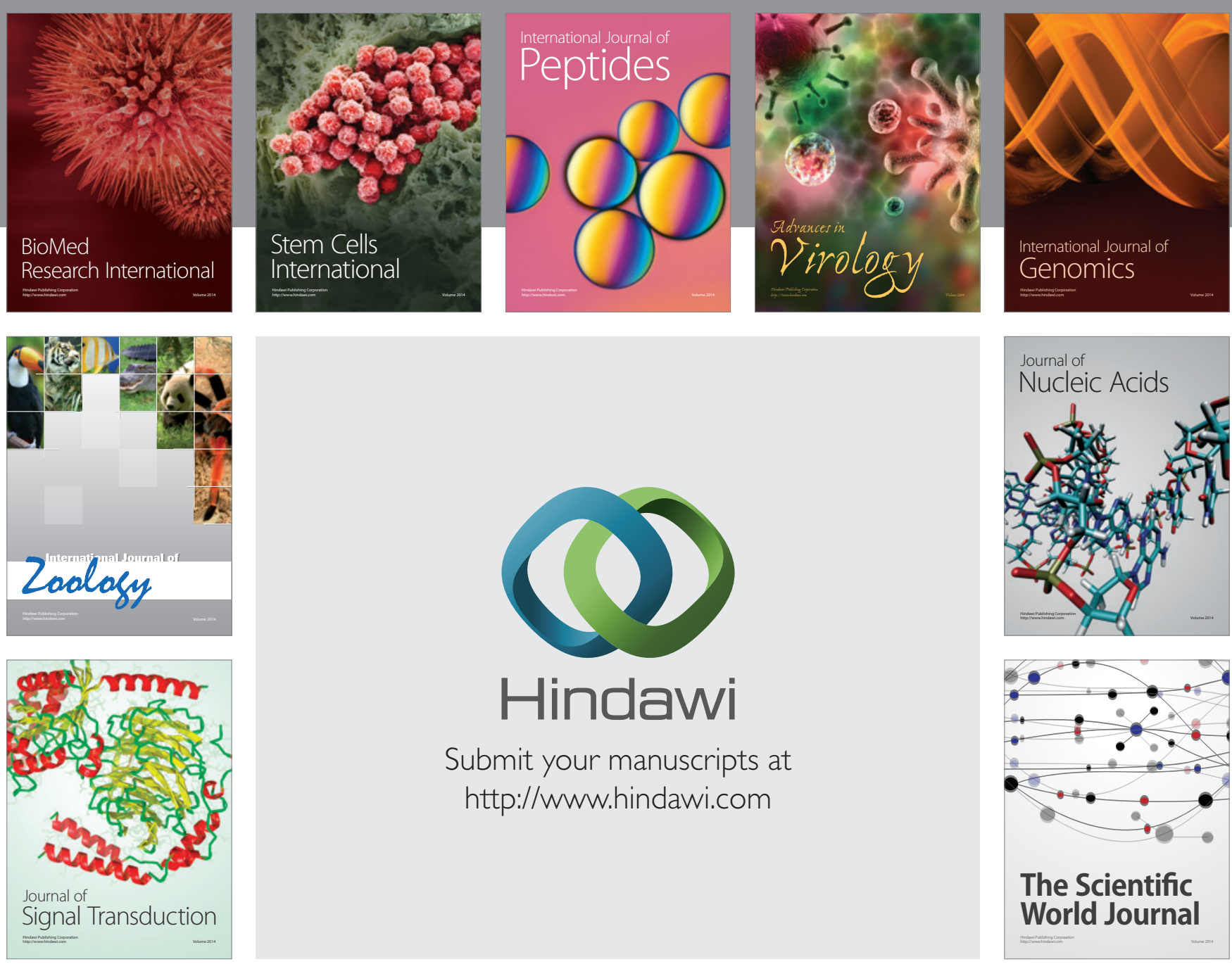

Submit your manuscripts at

http://www.hindawi.com
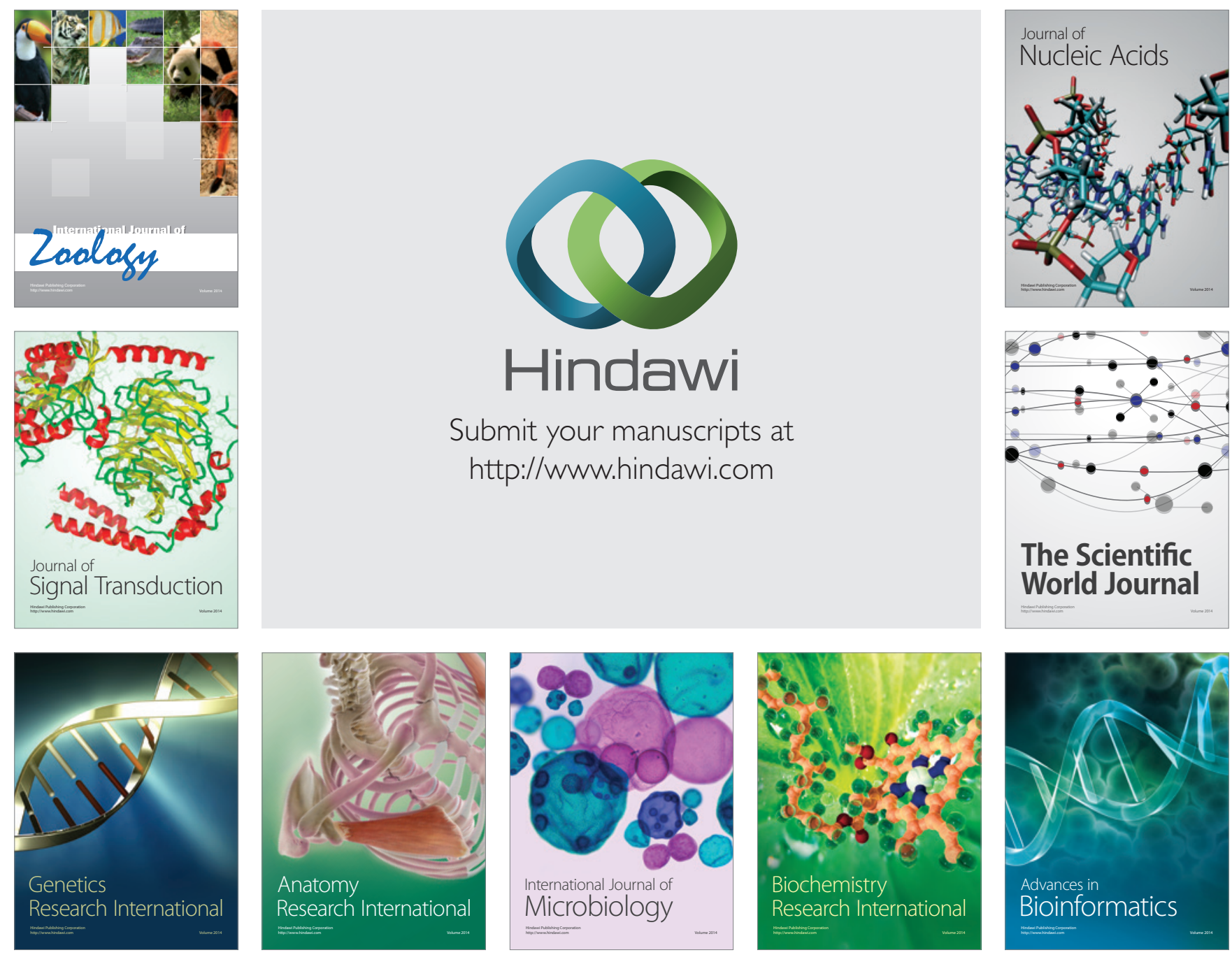

The Scientific World Journal
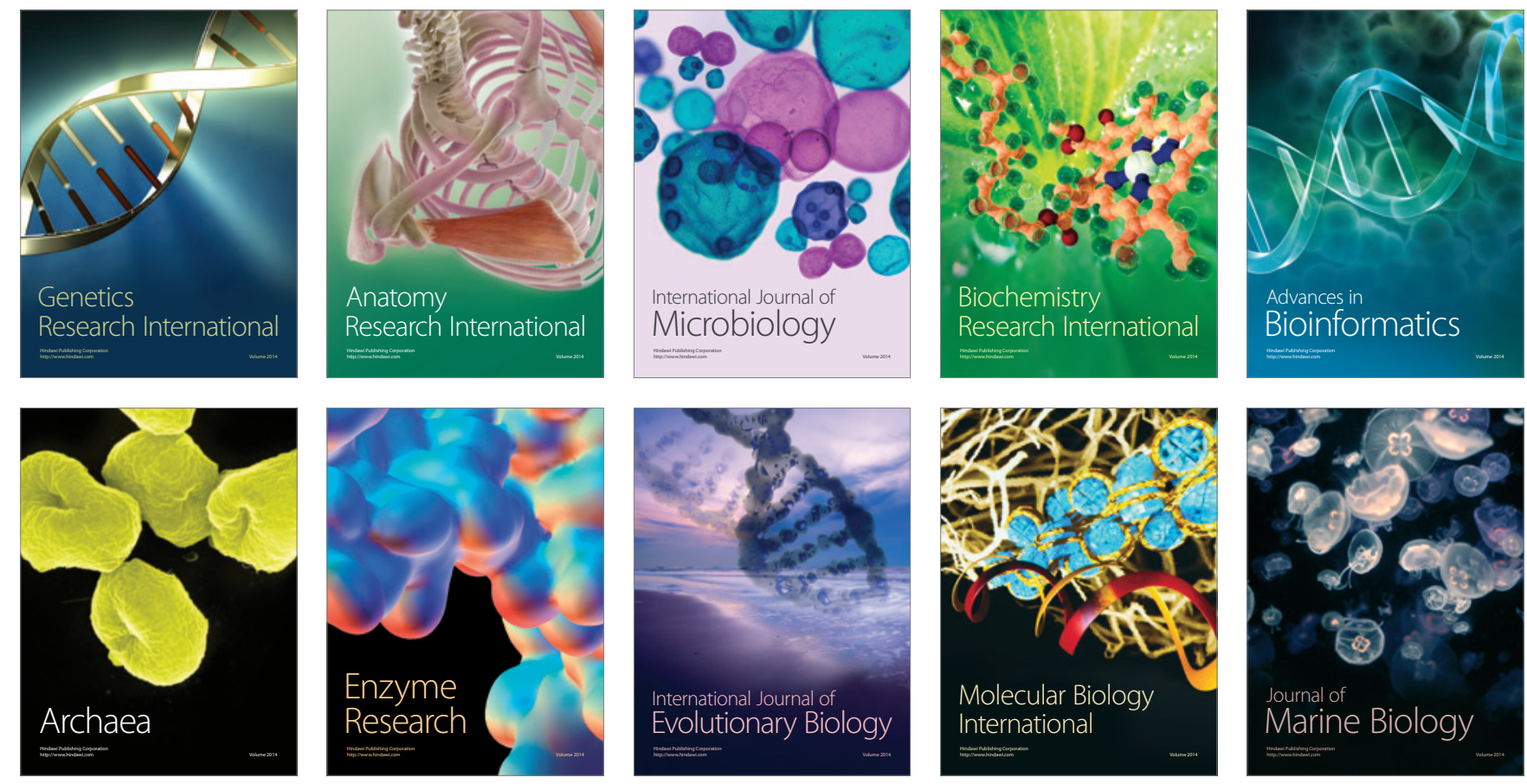